\title{
Evaluation and Improvement of Accurate Poverty Alleviation Performance in Poverty-stricken Areas: An Empirical Study Based on Ten Typical Poverty-stricken Villages in Hainan Province
}

\author{
Chenyu Zha \\ Department of international trade and economics in school of economics and management, Hainan University, \\ Hainan, 570228, China \\ Corresponding Author email: zha19970226@foxmail.com
}

Keywords: Poor rural areas; poverty alleviation performance; Hainan province; empirical study

\begin{abstract}
Accurate poverty alleviation is a strategic plan for the Party and the state in the new stage of poverty alleviation and development work. Accurate poverty alleviation performance in poor areas of Hainan Province is related to the overall situation of poverty alleviation in all poor cities, counties and the whole province. Based on the actual survey and data collection, this paper introduces clustering analysis algorithm to study the performance of 10 typical poverty-stricken villages in Changjiang and Lingao counties. It is found that there are "cluster effect" and "poverty trap" among different poor villages. Finally, based on the field survey and empirical results, this study puts forward suggestions for improving the performance of poverty alleviation in different types of poverty-stricken villages.
\end{abstract}

\section{Introduction}

Accurate poverty alleviation is a strategic plan for the new stage of poverty alleviation and development by the party and the state in the new era. In the past year, the CPC Central Committee and the State Council have explicitly called for the establishment of a precise poverty alleviation mechanism, the implementation of precise poverty alleviation, precise poverty alleviation. After the promulgation of the precise poverty alleviation policy by the CPC Central Committee, Hainan Province actively responded to the call of the state and put forward ten measures according to Hainan's actual situation to speed up the precise poverty alleviation of the poor population. In the 2017 Hainan Provincial Government Work Report, it emphasized that we should make every effort to combat poverty, put the "precision" requirement throughout the whole process of poverty alleviation, and implement the responsibility layer by layer. The report stresses the need to implement the responsibility system for poverty alleviation, implement the most stringent performance appraisal, and seriously investigate and punish the cases of poverty alleviation, poverty alleviation and digital poverty alleviation, so as to ensure that poverty alleviation is recognized by the masses and can stand the test of history. On the basis of comprehensive and in-depth understanding of accurate poverty alleviation, the team took ten poor villages in Hainan Province as an example to conduct in-depth field research in poor cities and counties.

\section{Data sources}

\subsection{Investigation method}

This research adopts the questionnaire survey method, altogether designs 22 topics. Among them, there are 7 basic conditions, 2 poverty awareness, 1 government and other financial aid, 2 consumer psychology and emotional state, and 1 awareness of fairness and autonomy. A total of 90 questionnaires were sent out in Changjiang County. 85 questionnaires were recovered with a recovery rate of $94.4 \%$. 85 questionnaires were valid and the effective rate was $100 \%$. A total of 90 
questionnaires were sent out in Lingao County, and 80 questionnaires were recovered. The recovery rate was $88.8 \%$. Among them, 80 questionnaires were valid and the effective rate was $100 \%$.

\subsection{The first stage of the survey}

Most of the poor people in the two impoverished villages in Changjiang County (Pieshi Village in Changhua Town and Dayan Village in Wangxia Township) and the two impoverished villages in Lingao County (Wentan Village in Lincheng Town and Baorui Village in Baorui Village) can face up to their living conditions, but some of the poor people will avoid facing up to their living conditions. The majority of the poor believe that the selection methods and results of the poor households are fair, but there are still a small number of people who think that it is unfair, and some people do not know how to select, there is no autonomy in the selection. Poor people are older, most of them are between 50 and 60 years old, with a lower education level. Primary school education accounts for 80 percent. Family income mainly comes from farming and state subsidies. The monthly living expenses of families are mainly used for food and medicine. The majority of the poor think they need donations from society. Most of the poor people have minimum allowances, few have medical insurance, and few have old-age insurance. Most people want financial help, but some poor people need people's care and psychological counseling, only a very small number of poor people think they need to learn to broaden their horizons. The results of this survey show that the poor people have a psychological dependence on others, and they hope to get help from others without learning and their own efforts. On the other hand, it can be seen that some poor people need love and psychological solutions.

\section{An empirical study on the performance evaluation scheme and model of precision poverty alleviation}

\subsection{Basic information and data introduction}

A total of 425 households were investigated in 10 impoverished villages including Changjiang County, Lingao County and Meishan Village. The first-hand survey data were obtained. Other data came from Hainan Statistical Bureau and relevant government documents and bulletins.

\subsection{Design of questionnaire scale}

This research refers to the questionnaire and scale of poverty alleviation performance evaluation of the project "Comprehensive Poverty Alleviation Development in Liangshan, Sichuan Province (2010-2015) pilot evaluation, 2013-2014" of the Information Center of the State Council Poverty Alleviation Office. Then, with the help of relevant school experts and the actual situation of poor areas in Hainan Province, the questionnaire has been properly adjusted, and the specific indicators are shown in Table 1.

Table 1 Specific indicators

\begin{tabular}{|c|c|c|}
\hline First level index & Two level index & Three level index \\
\hline & $\begin{array}{c}\text { Environmental } \\
\text { development goals }\end{array}$ & $\begin{array}{l}\text { The amount of compensation for ecological benefits (X1), } \\
\text { the output value of ecological characteristic industries (X } \\
\text { 2) }\end{array}$ \\
\hline & $\begin{array}{l}\text { Social development } \\
\text { goals }\end{array}$ & $\begin{array}{c}\text { Subsidies for education (X 3); Science and technology } \\
\text { training (X 4); Cement road construction mileage (X 5); } \\
\text { Agricultural Cooperative Medical Scheme (X 6) }\end{array}$ \\
\hline $\begin{array}{l}\text { Sustainable development } \\
\text { goal }\end{array}$ & $\begin{array}{l}\text { Economic development } \\
\text { goal }\end{array}$ & $\begin{array}{l}\text { Gross per capita income of farmers (X 7); the growth rate } \\
\text { of total income of the whole village (X 8); total per capita } \\
\text { consumption expenditure of farmers (X 9); } \\
\text { Average household fixed assets value at the end of the year } \\
\text { (X10) }\end{array}$ \\
\hline Poverty alleviation goal & $\begin{array}{l}\text { Poverty alleviation } \\
\text { performance }\end{array}$ & $\begin{array}{c}\text { The incidence of poverty (X11); the per capita livestock } \\
\text { stock of farmers (X12). }\end{array}$ \\
\hline
\end{tabular}




\section{Poverty alleviation performance evaluation}

\subsection{Poverty alleviation performance evaluation based on factor analysis}

The author uses SPSS 21.0 software to measure the factors of 10 poverty-stricken villages, and the data show that the index data are suitable for factor analysis. The comprehensive scores of poverty alleviation performance of Dazhang village, Baorui village and Meishan village are all above 1, so the poverty alleviation performance of these poor villages is considered to be higher than the average level. The comprehensive scores of poverty alleviation performance of Baotu village, Longdao village, Shuifu village and Wentan village are between 0 and 1 , so the poverty alleviation performance of these poor villages is relatively high, all above the average level. The comprehensive scores of poverty alleviation performance of Wenxin Village, Pieshi Village and Bolang Village are all below 0, which indicates that the poverty alleviation performance of Wenxin Village, Pieshi Village and Bolang Village is lower than the average level.

There are three main factors that have a major impact on poverty alleviation performance in poverty-stricken villages, namely, economic performance, ecological performance and social development performance. Therefore, this shows that the poverty alleviation performance of the poor villages in Hainan is mainly restricted by these three situations.

\subsection{Performance analysis of poverty alleviation based on clustering model}

The general scores of the previous papers were clustered with K- means to explore the common law of different poverty villages. We use 4 as the number of clusters. By means of SPSS21.0 software, the score of the comprehensive evaluation function of each poor village is clustered by means of Kmeans. The following is the change of cluster centers (Table 2) and the number of cases contained in each category. By combining the cluster model of principal component analysis, we classify the poverty-stricken villages into four categories, which lays the foundation for putting forward concrete measures.

Table 2 Clustering results integration

\begin{tabular}{cccc}
\hline Poor village & $\begin{array}{c}\text { Comprehensive } \\
\text { score }\end{array}$ & $\begin{array}{c}\text { Category } \\
\text { Da Zhang Village }\end{array}$ & $\begin{array}{c}\text { Distance from cluster } \\
\text { centers }\end{array}$ \\
\hline The village of holding Rui & 1.84 & 1 & 0 \\
Mei Shan Village & 1.39 & 2 & 0.17 \\
Bao Dong Village & 1.05 & 2 & 0.17 \\
Long Dao Village & 0.82 & 4 & 0.21 \\
Shui Fu Village & 0.7 & 4 & 0.09 \\
Wen Tan Village & 0.31 & 4 & 0.3 \\
Wenxin Village & 0.07 & 3 & 0.255 \\
Shek Village & -0.09 & 3 & 0.095 \\
The village of Bo & -0.17 & 3 & 0.015 \\
\hline
\end{tabular}

We can draw a conclusion from table 2 that Dazhang Village is the first category, Baorui Village and Meishan Village are the second category, Wentan Village, Wenxin Village, Sheshi Village and Bolang Village are the third category, Baotu Village, Longdao Village and Shuifu Village are the fourth category. In this way, we can study the underlying factors of poverty performance from a categorical perspective, thus laying the foundation for making recommendations. The results show that the first category is the best performance of poverty alleviation. Combining with our field research data, we found that the tourism industry in Dazhang Village is relatively developed, and has established a tourism cooperative. Therefore, the best performance of Dazhang Village is probably due to the establishment of tourism cooperatives and vigorous development of the tourism industry. Therefore, this practical measure is conducive to improving the performance of poverty alleviation and is worthy of promotion. The second category is sub optimal; the third is relatively poor; the fourth 
is the general level.

\section{Basic conclusions and suggestions}

\subsection{Poverty alleviation farm pilot project}

Baotu Village is located in the northwest of Hainan Island. It is a natural village of Li nationality with beautiful scenery. Therefore, we believe that the village can build a pilot project of poverty alleviation farming and promote the village to extricate itself from poverty. The government should attach great importance to the construction of beautiful countryside, effectively guide the people to shake off poverty and increase income for a long time, so that the people can truly share the benefits brought by green water and green mountains. We should actively explore the construction of a poverty alleviation farm to increase farmers' income, increase agricultural efficiency and increase rural beauty. On the basis of not changing the nature of village collective land, according to the local natural environment, topography and landform and market demand, the planning and construction of functional farms, to create a distinctive cluster of farms.

\subsection{Intensify infrastructure construction}

To get rich, infrastructure must keep pace, and the government can invest more and innovate financing models. Because many villages have beautiful natural scenery, we can try the idea of "tourism scenic area development + infrastructure construction" in rural infrastructure development and construction. On the one hand, the local infrastructure can be improved by using the funds of tourism development enterprises for infrastructure construction. Two, it can bring more employment opportunities to the villagers and help the work of helping the poor.

\subsection{Highlighting the characteristics and taking the road of promoting the village with characteristics}

In the villages investigated by the author, I found that although many villages have their own shortcomings, but also have their own characteristics, so these villages can make full use of their own characteristic resources to get rid of poverty and become rich. For example, after the relocation of Shuifu Village, the per capita land area is very small and the soil is barren, but the terrain is flat and the illumination is sufficient to develop the photovoltaic industry. The export of labor services in Pian Shi village is its characteristic. Bao Tu village's pottery craft, water Fu Village's Cowhide stool, and so on. The government can focus on supporting these projects, making them bigger and stronger, and become a new engine for the villagers to get rid of poverty and become rich.

\subsection{Combining the rural cooperative medical system with the serious illness relief system}

Particularly, we should increase subsidies to poor households, and focus on solving the problem of poverty caused by illness and returning to poverty due to illness in the vast rural poverty-stricken areas.

\subsection{Ecological poverty relief immigrants}

Villages with very poor basic conditions and scarce natural resources, such as Wentan Village, can learn from the experience of ecological migration and carry out overall relocation, which is the most effective way to alleviate poverty.

\section{References}

[1] Agrawal A, Kapur D, Mchale J, et al. Brain drain or brain bank? The impact of skilled emigration on poor-country innovation [J]. Journal of Urban Economics, 2011, 69(1):43-55.

[2] Jr S R, Sarwari A R, Siddiqui A R. Crimean-Congo hemorrhagic fever: prevention and control limitations in a resource-poor country.[J]. Clinical Infectious Diseases, 2004, 38(12):1731-1735. 
[3] Omidiji O A, Campbell P C, Irurhe N K, et al. Breast cancer screening in a resource poor country: Ultrasound versus mammography.[J]. Ghana Med J, 2017, 51(1):6-12.

[4] Hassan H, Rajiv K R, Menon R, et al. An audit of the predictors of outcome in status epilepticus from a resource-poor country: a comparison with developed countries [J]. Epileptic Disorders, 2016, 18(2):163-172.

[5] Schumacher R. Adam Smith and the "rich country-poor country" debate: eighteenth-century views on economic progress and international trade [J]. European Journal of the History of Economic Thought, 2016, 23(5):1-30. 